IRSTI 06.81 .55

UDC 338.24

M.T. DAVLETOVA, ${ }^{1}$

c.e.s., associate professor.

K.SH. SYZDYKOVA, ${ }^{2}$

c.e.s., associate professor.

Kazakh University of International Relations and World Languages named after Abylai Khan. ${ }^{1}$

Kainar University ${ }^{2}$

\title{
INNOVATIVE TECHNOLOGIES IN KAZAKHSTAN
}

The article is devoted to the development of innovative technologies in Kazakhstan. Recently, the world has been flooded with new ideas, gadgets, applications, a staggering number of innovative technologies are being developed that are capable of fundamentally transforming goods and production processes: nanotechnology, 3D printers, robotics, industrial Internet, additive, disruptive, subtractive technologies. Artificial intelligence, voice control and virtual reality are the times when science fiction is slowly becoming a reality. Among other innovative technologies is a face recognition system developed by Kazakhstani specialists. In Kazakhstan, Tech Garden and Astana Hub projects help innovators develop innovative ideas by providing them with infrastructure, financial support, mentoring, access to investors and opportunities to exchange experiences with foreign innovators. The development of innovations directly depends on the support from the state and business of scientific research work. In order for Kazakhstani specialists not only to introduce innovative technologies into the practice of their company, but also to develop and offer new ideas, products, projects and gadgets themselves, it is necessary to create favorable conditions and encourage them accordingly, for example, the creation of special workspaces for young professionals (technology hubs, business incubators, innovation centers).

Key words: innovative technologies, smart home, Internet of things, 5G technologies, technology hubs, business incubators, artificial intelligence, virtual reality.

Kazakhstan is confidently moving along the path of development and implementation of new technological solutions and occupies the 74th position in the ranking of the Global Innovation Index [1].

According to Askar Aituov, Tech Garden Projects Project Director, the innovation mainstream will also have various applications of blockchain technology, Industry 4.0, IoT, Artificial intelligence solutions, the creation of new materials, additive technologies in the form of various variations of 3D digital printing and new energy.

According to the director of the MOST business incubator Alim Khamitov, "the most relevant technologies today, which offer great opportunities, are artificial intelligence, augmented and virtual reality, the Internet of Things (IoT) and, of course, blockchain" [1].

In 2017, the National Agency for Technological Development (NATD), together with the MOST business incubator, compiled a rating of the most innovative Kazakhstani companies in Kazakhstan. There are 10 companies in the ranking: Eurasian Group, KunTech, Samruk-Energy, Kazatomprom, SAPA, Beeline Kazakhstan, Tau Innovative Solutions, Air Force Engineering, Mercury Properties and PolyTech Electronics [2].

Beeline Kazakhstan, for example, annually invests up to $20 \%$ of revenue in the creation of innovative products. In 2017, the company tested the communications standard for the "Internet of Things". The technology allows you to automatically transfer data from gas meters through the cellular network to the management company. Its task is to improve the gas supply service, making it safer. The innovative system is designed for the projects "Smart Home" and "Smart City" [2].

Just imagine that you are driving home from work, while your car or mobile phone transmits a signal, and your "smart home" is ready to meet its owner: the heating is on, the floor is heated, the warm bath is set, dinner is getting ready... Just a few years ago it seemed fantastic. Today, with the development of Internet of Things (IoT) and M2M (machine-to-machine) technology, the future is getting closer.

For residents of the United States and Europe, smart home devices are gradually becoming commonplace, like a smartphone: lamps and sockets with an Internet connection are now available 
in almost every home. Home appliances with the prefix "smart" appear in our everyday life more and more often: a smartphone, smart TV, smart refrigerators and other "smart" gadgets. In Kazakhstan, the concept of a smart home has not yet become widespread, but the market and demand have already begun to take shape.

For example, the Kazakhtelecom company, which provides a full cycle of telecommunication services, has great prospects to conquer the market of "smart homes" and "smart offices". Today, the company is able to provide an integrated approach to the organization of work: a communication channel, special equipment, as well as a decent level of service [3].

Kazakhtelecom JSC already provides a cloud-based video surveillance service that enables users to make their offices and homes more secure. The subscriber can remotely, using the application in real time, monitor what is happening at his home or in the office. The company needs to go further and expand the range of services for the "smart home" or "smart office".

The concept of "Smart Home" is a complete solution for providing home security using a mobile application; a system of modern technologies for a safe, economical and comfortable life in the house.

Key features of the system:

- monitoring of events in the subscriber's premises by means of an IP video camera and a set of sensors, through a mobile application on a smartphone in real time. The application is available on the platforms: Android, iOS;

- receiving and collecting information from installed sensors with push notification of events that have occurred and an archive of events;

- in the future, it will be possible to write scenarios for controlling a set of sensors and an IP video camera;

- the ability to locally save video data on a computer [3].

Target product segment:

- subscriber - owner, tenant of the apartment / house;

- subscriber - a family who needs to ensure safety in the house, including:

1) monitoring household members (for example, children, elderly parents);

2) monitoring the safety of real estate and its property;

- the subscriber must be connected to the services of broadband Internet access from Kazakhtelecom.

The basic set of equipment will include one IP video camera and a set of sensors: movement, opening doors, opening windows, temperature and humidity sensors, a smoke detector (serena), gas leakage sensor, water leakage sensors, smart sockets. At the request of the subscriber, an additional set of cameras and sensors can be installed.

In order to activate the Smart Home service, the subscriber needs to submit an application at the points of Kazakhtelecom JSC's own service network, which will provide technical support to users [3].

About a dozen domestic innovative products that have gained recognition outside of Kazakhstan are associated with the e-commerce market, which is developing at a rapid pace.

The largest, noted by competitors, success can be called the history of the only domestic manufacturer of POS-terminals - the company Smart Pay. Their "smart" terminal replaces expensive equipment, provides access to cloud technologies, and allows small and medium-sized businesses to transparently sell and accept any type of cashless payments. Thanks to Smart Pay today, Kazakhstanis are available, for example, an online payment service for the use of toll roads [1].

Kazakhstan was one of the first to introduce $3 \mathrm{G}$ and $4 \mathrm{G}$ technologies, and also intends to introduce $5 \mathrm{G}$ one of the first in the world. According to Sanjar Kettebekov, Director General of the Autonomous Cluster Fund of the special economic zone Alatau Innovation Technologies Park, 5G networks may appear in Kazakhstan by 2020 [4]. "Now in PIT, two unique projects with the involvement of multinational companies are under development. The first - regarding the production of Kazakhstani computer equipment with a foreign company IMS. Another project is fifth-generation mobile communications technology". "This is a non-standard thing and requires long testing, because for the introduction of $5 \mathrm{G}$ in Kazakhstan, you need to sell not just iron, but a service. That is, the operator must understand how he can monetize this infrastructure", S. Kettebekov noted [4].

He also added that the installation of test platforms in Nur-Sultan and Almaty is currently planned. By the end of 2019 - the beginning of 2020, test platforms will be launched, and their commissioning 
is scheduled for four years [4]. Thus, a pilot project is already underway, but phones that support 5G are also needed.

Among other innovative technologies can be called a face recognition system developed by Kazakhstani specialists [5].

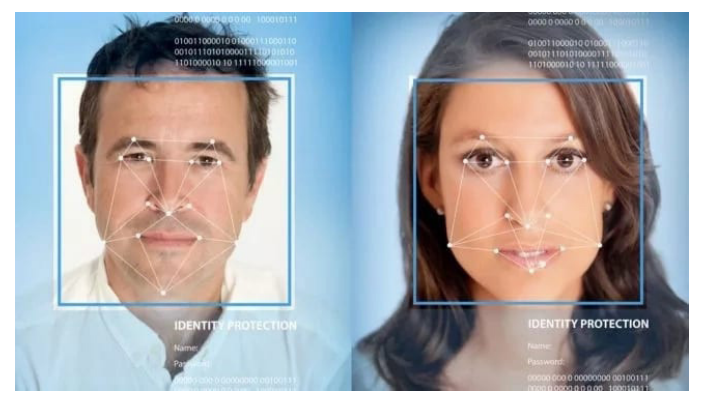

Figure 1 - Face recognition system developed in Kazakhstan

However, these developments have not yet received funding and are closed, i.e. technologies will not be transferred to foreign experts due to their secret status. A possible field of application of the face recognition system is the Smart City project.

In Kazakhstan's IT sphere, one can cite dozens of examples of how a good new solution, as a result, rested on an unworked design or insufficient user experience. And as a result, an innovative product was not in demand by the market.

Therefore, it is necessary to create favorable conditions and accordingly stimulate Kazakhstani specialists so that they not only introduce innovative technologies into the practice of their company, but also develop and propose new ideas, products, projects and gadgets.

The development of innovations directly depends on the support from the state and business of research work, the creation of special educational programs for young scientists and innovators, and the spaces where they could develop innovative technologies.

Countries with the most innovative economies, such as Switzerland, the Netherlands, the UK and Singapore, are also leaders in the costs of research projects and education at local universities.

A favorable innovative environment implies the creation of special workspaces for young professionals. Such sites are called technology hubs, business incubators, acceleration centers, and become innovation centers if professional communities and start-up communities are formed and developed in them. They often become a practical and research base for students of local universities. Most of these spaces today in the United States and Europe. Recently, similar projects appear in the CIS, including in Kazakhstan [2].

In 2016, in accordance with "100 concrete steps to implement the five institutional reforms" innovative projects appeared in Kazakhstan: local Tech Garden acceleration and international Startup Kazakhstan acceleration; the program "100 startups" of Astana Hub [2].

\section{LIST OF LITERATURE}

1 The global trend for innovation. Kazakhstan is a regional leader capable of more: // https://informburo. kz/stati/globalnyy-trend-na-innovacii-kazahstan-regionalnyy-lider-sposobnyy-na-bolshee.html.

2 What is innovation, and how are they developing in Kazakhstan: // https://informburo.kz/cards/chtotakoe-innovacii-i-kak-oni-razvivayutsya-v-kazahstane-.html.

3 Official site of Kazakhtelecom JSC / Other services / Smart home: // https://telecom.kz/ru/common/ smart_house.

4 By 2020, 5G networks may appear in Kazakhstan: // https://www.nur.kz/803742-k-2020-godu-vkazakhstane-mogut-poyavitsya-s.html

5 A face recognition system is being developed in Kazakhstan: // https://www.nur.kz/1731646-sistemuraspoznavania-lic-razrabatyvaut-v-kazahstane.html. 
М.Т. ДӘУЛЕТОВА,

э.Ғ.к., доцент.

К.Ш. СЫЗДЫКОВА,

э.ғ.к., доцент.

Абылай хан атындағы Қазақ халықаралық қатынастар және әлем тілдері университеті. ${ }^{1}$

«Қайнар» университеті ${ }^{2}$

\title{
ҚАЗАКСТАНДАҒЫ ИННОВАЦИЯЛЫҚ ТЕХНОЛОГИЯЛАР
}

Мақала Қазақстандағы инновациялық технологияларды дамытуға арналған. Жақында әлем жаңа идеялармен, гаджеттермен, қосымшалармен толықты, тауарлар мен өндіріс процестерін түбегейлі өзгертуге қабілетті көптеген инновациялық технологиялар жасалып жатыр: нанотехнология, 3D принтерлер, робототехника, өнеркәсіптік (өнеркәсіптік) интернет, аддитивті, дизрабтивті, субтрактивті технологиялар. Жасанды интеллект, дауыстық бақылау және виртуалды шындық - бұл ғылыми фантастика біртіндеп шындыққа айналатын уақыт. Тағы бір инновациялық технологиялардың бірі - қазақстандық мамандар жасаған бетті тану жүйесі. Қазақстанда Tech Garden және Astana Hub жобалары инноваторларға инновациялық идеяларды дамытуға көмектеседі, оларға инфрақұрылым, қаржылық қолдау, тәлімгерлік, инвесторларға қол жетімділік және шетелдік инноваторлармен тәжірибе алмасу мүмкіндіктері беріледі. Инновациялардың дамуы мемлекет пен бизнестің ғылыми-зерттеу жұмыстарын қолдауына тікелей байланысты. Қазақстандық мамандар инновациялық технологияларды өз компаниясының тәжірибесіне енгізіп қана қоймай, сонымен қатар жаңа идеяларды, өнімдерді, жобалар мен гаджеттерді өздері әзірлеп, ұсына алуы үшін қолайлы жағдайлар жасап, оларды сәйкесінше ынталандыру қажет, мысалы, жас мамандарға арналған арнайы жұмыс орындарын құру (технологиялық хабтар, бизнес-инкубаторлар, инновациялық орталықтар).

Тірек сөздер: инновациялық технологиялар, ақылды үй, интернет заттары, 5G-технологиялары, технологиялық хабтар, бизнес-инкубаторлар, жасанды интеллект, виртуалды шындық.

М.Т. ДАВЛЕТОВА, ${ }^{1}$ к.э.н., доцент.

К.Ш. СЫЗДЫКОВА, 2

к.э.н., доцент.

Казахский университет международных отношений и мировых языков им. Абылай-хана. ${ }^{1}$ Университет «Кайнар»²

\section{ИННОВАЦИОННЫЕ ТЕХНОЛОГИИ В КАЗАХСТАНЕ}

\begin{abstract}
Аннотация
Статья посвящена развитию инновационных технологий в Казахстане. В последнее время мир захлестнули новые идеи, гаджеты, приложения, разрабатывается ошеломляющее количество инновационных технологий, которые способны коренным образом преобразовать товары и производственные процессы: нанотехнологии, 3D принтеры, робототехника, промышленный (индустриальный) интернет, аддитивные, дизрабтивные, субтрактивные технологии. Искусственный интеллект, голосовое управление и виртуальная реальность - это время, когда научная фантастика постепенно становится реальностью. В числе других инновационных технологий - система распознавания лиц, разработанная казахстанскими специалистами. В Казахстане проекты Tech Garden и Astana Нub помогают инноваторам развивать инновационные идеи, предоставляя им инфраструктуру, финансовую поддержку, менторство, доступ к инвесторам и возможности для обмена опытом с зарубежными инноваторами. Развитие инноваций также напрямую зависит от поддержки государством и бизнесом научно-исследовательской работы. Чтобы казахстанские специалисты не только внедряли инновационные технологии в практику деятельности своей компании, но и сами разрабатывали и предлагали новые идеи, продукты, проекты и гаджеты, необходимо создавать благоприятные условия и соответствующим образом стимулировать их, например, создание специальных рабочих пространств для молодых специалистов (технологических хабов, бизнес-инкубаторов, центров инноваций).
\end{abstract}

Ключевые слова: инновационные технологии, умный дом, интернет вещей, 5G-технологии, технологические хабы, бизнес-инкубаторы, искусственный интеллект, виртуальная реальность. 